\title{
SISTEM PENDUKUNG KEPUTUSAN DALAM MENENTUKAN SISWA BARU KELAS UNGGULAN DENGAN METODE MOORA (Studi Kasus : MTs N 1 LOMBOK TENGAH)
}

\author{
${ }^{*}$ Sofiansyah Fadli ${ }^{1,}$ Maulidya Rizqi ${ }^{2}$ \\ 1,2,3STMIK Lombok, Teknik Informatika, Indonesia \\ sofiansyah182@gmail.com ${ }^{1,}$ maulidyarizqi@gmail.com² \\ * Correspondingauthor
}

\begin{abstract}
Abstrak
Siswa kelas unggulan merupakan siswa yang terdiri dari orang-orang pilihan yang memiliki kemampuan yang lebih menonjol bila dibandingkan dengan siswa kelas biasa. MTs N 1 Lombok Tengah merupakan salah satu sekolah yang sudah menerapkan adanya pemilihan kelas unggulan dimana tiap tahunnya sekolah tersebut menyeleksi ratusan siswa baru untuk masuk ke kelas unggulanyang hanya diperuntukkan untuk 60 siswa baru (2 kelas). Proses pemilihannya masih menggunakan sistem manual, yaitu dilihat dari nilainilai yang sudah ditentukan berdasarkan kriteria-kriteria yang ada. Pemilihan dengan cara tersebut akan membutuhkan waktu yang cukup lama sehingga tidak efektif dan efesien. Pada penelitian ini, metode yang digunakan untuk menentukan siswa baru kelas unggulan yaitu MultiObjectiveOptimizationonthebasicofRatioAnalysis (MOORA)dimana diperlukan proses normalisasi dalam perhitungan ini. Hasil penelitian dengan metode MOORA membuktikan bahwa aplikasi ini dapat membantu Panitia dalam proses penyeleksian siswa baru kelas unggulan.
\end{abstract}

\section{Keywords - DecisionSupport System, MOORA Methode, New Classof Superior Students.}

\section{Latar Belakang}

Pendidikan merupakan hal mutlak yang harus dilakukan. Fungsi utama pendidikan yaitu untuk mengembangkan potensi peserta didik. Membangun sekolah dengan menerapkan kelas unggulan juga sangan diperlukan, karena motivasi siwa dalam belajar juga tergantung dari lingkungannya. Jika lingkungannya dipenuhi dengan orang-orang yang rajin maka motivasi belajarnya akan semakin kuat. Proses pembagian kelas setiap tahun ajaran baru biasanya masih dilakukan secara konvensional, yakni dengan metode acak maupun metode pengurutan dan belum melibatkan kemajuan dibidang teknologi informasi [5]. Keterlibatan tekhnologi informasi hanya digunakan untuk mengurutkan jumlah nilai siswa. Dengan menggunakan spreadsheet, pembuatan daftar calon dengan urutan prestasi dari yang paling pandai sampai yang paling lemah dapat dilakukan dengan mudah. Untuk menyeleksi calon siswa yang diterima cukup dengan mengambil sejumlah calon siswa yang terdapat pada ranking paling atas sesuai dengan kapasitas. Calon siswa yang berada pada urutan diluar kapasitas, dinyatakan tidak diterima. Proses pembagian kelas seperti ini mengakibatkan terjadinya berbagai masalah. Persoalan pengambilan keputusan pada dasarnya adalah bentuk pemilihan dari berbagai alternatif tindakan yang mungkin dipilih yang prosesnya melalui mekanisme tertentu dengan harapan akan menghasilkan keputusan terbaik [11]. Keputusan yang diambil biasanya dilakukan berdasarkan pertimbangan situasional, bahwa keputusan tersebut adalah keputusan terbaik.

Kelas unggulan dikembangkan untuk mencapai keunggulan dalam keluaran pendidikan sebagai model kelas dalam rangka peningkatan mutu pendidikan. 
Pemilihan siswa kelas unggulan yang berkualitas akan sangat berpengaruh terhadap proses pembelajaran. Kelas Unggulan dirancang untuk memberikan pelayanan belajar yang memadai bagi siswa yang benar-benar mempunyai kemampuan yang luar biasa. Pemberian pelayanan pembelajaran khusus tersebut dilakukan agar potensi anak berbakat dapat berkembang secara optimal [10]. Didalam memilih siswa yang layak menempati kelas unggulan tidak bisa hanya dengan berdasarkan pengetahuan atau peringkat saja, akan tetapi diperlukan beberapa kriteria.

Undang-undang No. 20 Tahun 2003 tentang Sistem Pendidikan Nasional mengamanatkan tentang perlunya memberikan pendidikan khusus bagi peserta didik yang memiliki potensi dan kecerdasan istimewa. Hal ini dilakukan agar potensi yang dimiliki peserta didik dapat berkembang sehingga mereka dapat tumbuh menjadi manusia yang beriman dan bertakwa kepada Tuhan Yang Maha Esa, serta berguna bagi bangsa dan Negara [14].

MTs N 1 Lombok Tengah merupakah salah satu sekolah yang sudah menetapkan adanya kelas unggulan. Kelas unggulan mulai dipilih dari kelas VI ketika peserta didik mendaftar ke sekolah tersebut. Adapaun syarat yang harus dilalui peserta didik sehingga dapat masuk ke kelas unggulan tersebut, yaitu : nilai Raport, mempunyai piagam, nilai ujian nasional, nilai ujian seleksi, dan nilai mengaji. Tapi dalam proses penyeleksiannya, pihak penyeleksi melakukannya secara manual, seperti ketika siswa mendaftar untuk mengikuti tes masuk ke kelas unggulan, para panitia penyeleksi akan memeriksa satu persatu, kemudian akan memberikan perankingan secara manual sehingga kemungkinan akan adanya kesalahan [6]. Untuk menanggulangi masalah tersebut maka diperlukan suatu sistem yang mampu membatu pihak penyeleksi dalam memilih mana siswa yang bisa masuk ke kelas unggulan dan mana siswa yang tidak bisa masuk ke kelas unggulan dengan memperhatikan kriteria yang digunakan. Dengan strategi ini, maka diharapkan akan mampu mencetak generasi penerus yang unggul. Sistem pengambil keputusan atau Decision Support System (DSS) adalah sebuah sistem yang digunakan sebagai alat bantu menyelesaikan masalah untuk membantu pengambil keputusan (manajer) dalam menentukan keputusan, tetapi tidak untuk menggantikan kapasitas manajer, hanya memberikan pertimbangan (Turban, 2012).

\section{Metode}

\section{Multi-Objective Optimization on the basic of Ratio} Analysis (MOORA)

Metode Moora adalah multiobjectif sistem yang mengoptimalkan dua atau lebih atribut yang saling bertentangan secara bersamaan. Metode ini diterapkan untuk memecahkan masalah dengan perhitungan matematika yang kompleks. Metode MOORA diperkenalkan oleh Brauers dan Zavadkas (2008)[4]. Metode ini pertama kali digunakan oleh Braurers pada tahun 2004 dalam suatu pengambilan dengan multikriteria. Metode moora banyak diaplikasikan dalam bidang seperti bidang manajemen, bangunan, kontraktor, desain jalan, dan ekonomi. Metode ini memiki tingkat selektifitas yang baik dalam menentukan suatu alternatif. Pendekatan yang dilakukan MOORA didefinisikan sebagai suatu proses secara bersamaan guna mengoptimalkan dua atau lebih yang saling bertentangan pada beberapa kendala [8]. Metode MOORA memiliki fleksibilitas dan kemudahan untuk dipahami dan dipisahkan bagian subjektif dari suatu proses evaluasi ke dalam kriteria bobot keputusan dengan beberapa atribut pengambil keputusan [10]. Metode ini memiliki tingkat selektifitas yang baik dalam menentukan sebuah alternatif. [2] Dimana kriteria yang bernilai menguntungkan (benefit) atau yang tidak memiliki keuntungan (cost). Langkahlangkah penyelesaian masalah menggunakan metode MOORA, antara lain:
a. Membuat matriks keputusan $x 11 \quad x 12 \quad x m n$
$\mathrm{X}=\left\lfloor\begin{array}{lll}x 21 & x 22 & x \mathrm{mn}\end{array}\right\rfloor$ $x 31 \quad x 32 \quad x m n$

b. Melakukan normalisasi terhadap matriks $x$ $\mathrm{X}^{*}{ }_{\mathrm{ij}}=\frac{X i j}{\sum_{i=1}^{m} x i j^{2}}$

c. Menentukan matriks normalisasi terbobot

d. Menentukan hasil preferensi $\mathrm{Yi}=\sum_{j=1}^{g} w j X * i j-\sum_{j=g+1}^{n} w j X * i j$

\section{Contoh Kasus dan Perhitungan}

Evaluasi penilaian Produk Curling Iron Terbaik dari 6 produk alternatif yang akan dibeli. Akan dipilih satu produk terbaik berdasarkan kriteria-kriteria yang telah ditentukan. Konsepnya adalah mencari produk Curling Iron yang memiliki karakteristik terbaik dari beberapa atribut/kriteria yang dinilai.

\section{Data Awal}

Dalam contoh kasus ini diperoleh data awal sebagai berikut:

Tabel 2.1 Data Produk Sebelum di-Fuzzy-kan

\begin{tabular}{|c|c|c|}
\hline Kode & Bahan & Harga \\
\hline$A_{1}$ & $\begin{array}{c}\text { Panasonic HHW17K Hair } \\
\text { Straightener }\end{array}$ & Keramik \\
\hline $\mathrm{A}_{2}$ & Sonar Tourmalin SN-1071 & Tourmalin \\
\hline
\end{tabular}

Program Studi Teknik Informatika

Universitas Prima Indonesia (UNPRI) Medan 


$\begin{array}{ccc}\mathrm{A}_{4} & \text { Wand Interchangeable } 3 \text { Parts } & \text { Keramik } \\ \mathrm{A}_{5} & \text { Sayota Curly HC } 80 & \text { Stainless } \\ \mathrm{A}_{6} & \text { Philips Curly HP 8605 } & \text { Keramik }\end{array}$

\begin{tabular}{cccc}
\hline $\begin{array}{c}\text { Pengatur } \\
\text { Suhu }\end{array}$ & Ukuran & Garansi & Bahan \\
\cline { 1 - 1 } 360.000 & Ya & $31 \times 20 \times 31$ & 1 Tahun \\
287.000 & Ya & $40 \times 32 \times 60$ & Tidak Ada \\
249.000 & Ya & $20 \times 5 \times 10$ & 1 Bulan \\
289.000 & Ya & $1 \times 1 \times 1$ & Tidak Ada \\
125.000 & Tidak & $30 \times 10 \times 10$ & Tidak Ada \\
575.000 & Ya & $20 \times 5 \times 10$ & 1 Tahun
\end{tabular}

\section{Bilangan Fuzzy Tiap Kriteria}

Berdasarkan data di atas, selanjutnya di fuzzy kan. Berikut pemberian nilai masing-masing kriteria. Enam bilangan fuzzy, yaitu Sangat Buruk (SB1), Buruk (B1), Cukup (C), Baik (B2), Cukup Baik (CB) Sangat Baik (SB2).

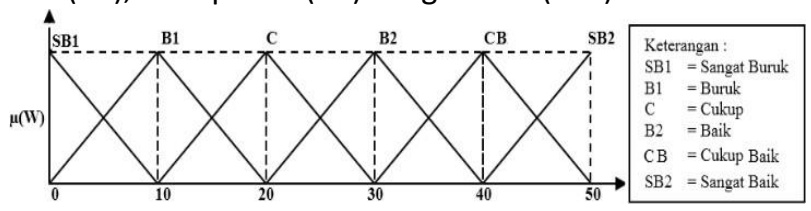

Nilai Bilangan Fuzzy Untuk Kriteria Bahan Pembuatan Tabel 2.2 Nilai Fuzzy kriteria Bahan Pembuatan

\begin{tabular}{|c|c|c|}
\hline Bahan & Bilangan Fuzzy & Nilai \\
\hline Tourmalin & Sangat baik & 50 \\
\hline Keramik & Cukup Baik & 40 \\
\hline Aluminium & Baik & 30 \\
\hline Stainles & Cukup & 20 \\
\hline Besi & Buruk & 10 \\
\hline
\end{tabular}

Nilai Bilangan Fuzzy Untuk Kriteria Harga

Tabel 2.3 Bilangan Fuzzy Kriteria Harga

\begin{tabular}{|c|c|c|}
\hline Harga & Bilangan Fuzzy & $\underline{\text { Nilai }}$ \\
\hline $50.000-250.000$ & Sangat Baik & 50 \\
\hline $251.000-450.000$ & Cukup Baik & 40 \\
\hline $451.000-650.000$ & Baik & 30 \\
\hline
\end{tabular}

Nilai Bilangan Fuzzy Untuk Kriteria Pengatur Suhu Tabel 2.4 Nilai Bilangan Fuzzy Kriteria Pengatur Suhu

Dilengkapi Bilangan Fuzzy Nilai

Pengatur Suhu

$\begin{array}{ccc}\text { Ya } & \text { Sangat Baik } & 50 \\ \text { Tidak } & \text { Buruk } & 20\end{array}$

Nilai Bilangan Fuzzy Untuk Kriteria Ukuran

Tabel 2.5 Nilai Bilangan Fuzzy Kriteria Ukuran

Ukuran ( $\mathrm{P} \times \mathrm{L} \times \mathrm{T}) \quad$ Bilangan Fuzzy Nilai

\begin{tabular}{ccc}
\hline $1 \times 1 \times 1-15 \times 15 \times 15$ & Sangat baik & 50 \\
$16 \times 16 \times 16-30 \times 30 \times 30$ & Cukup Baik & 40 \\
$31 \times 31 \times 31-45 \times 45 \times 45$ & Baik & 30 \\
$46 \times 46 \times 46-60 \times 60 \times 60$ & Cukup & 20 \\
$61 \times 61 \times 61-75 \times 75 \times 75$ & Buruk & 10
\end{tabular}

Nilai Bilangan Fuzzy Untuk Kriteria Garansi

Tabel 2.6 Nilai Bilangan Fuzzy Kriteria Garansi

\begin{tabular}{|c|c|c|}
\hline Garansi & Bilangan Fuzzy & Nilai \\
\hline$>=1$ tahun & Sangat baik & 50 \\
\hline$<=1$ tahun & Cukup Baik & 40 \\
\hline Tidak ada & Baik & 30 \\
\hline
\end{tabular}

Input Nilai Fuzzy setiap Alternatif

Berdasarkan nilai-nilai fuzzy dari tiap kriteria yang sudah ditentukan sebelumnya, nilai kriteria pada masing-masing alternatif yang ada pada tabel 1 sebelumnya menjadi seperti berikut ini:

Tabel 2.7 Nilai Fuzzy Setiap Kriteria untuk Setiap

\begin{tabular}{ccl}
\multicolumn{3}{c}{ Alternatif } \\
\hline Kode & Merk & Bahan \\
\hline $\mathrm{A}_{1}$ & $\begin{array}{c}\text { Panasonic HHW17K Hair } \\
\text { Straightener }\end{array}$ & 40 \\
& Sonar Tourmalin SN-1071 & 50 \\
$\mathrm{~A}_{2}$ & Rui Zhi Tools Curling Iron & 30 \\
$\mathrm{~A}_{3}$ & Wand Interchangeable 3 & 40 \\
$\mathrm{~A}_{4}$ & $\quad$ Parts \\
\multicolumn{3}{c}{ Sayota Curly HC 80 } \\
$\mathrm{A}_{5}$ & Philips Curly HP 8605 & 20 \\
$\mathrm{~A}_{6}$ &
\end{tabular}

\begin{tabular}{|c|c|c|c|}
\hline Harga & Pengatur Suhu & Ukuran & Garansi \\
\hline 40 & 50 & 30 & 50 \\
\hline 40 & 50 & 30 & 30 \\
\hline 50 & 50 & 40 & 40 \\
\hline 40 & 50 & 50 & 30 \\
\hline 50 & 20 & 40 & 30 \\
\hline 30 & 50 & 40 & 50 \\
\hline
\end{tabular}

\section{Menentukan Jenis dan Bobot Kriteria}

Berikutnya adalah menentukan jenis tiap kriteria, yaitu termasuk kriteria benefit atau cost. Penentuan ini berdasarkan informasi:

$\checkmark$ Benefit : Jenis kriteria jika nilai semakin besar maka semakin baik, jika semakin kecil maka bernilai tidak baik

$\checkmark$ Cost : Jenis kriteria jika nilai semakin kecil maka semakin baik, jika semakin besar maka bernilai tidak baik Dan ditentukan juga nilai bobot dari masingmasing kriterianya sebagai berikut 
Tabel 2.8 Jenis dan Bobot Setiap Kriteria

\begin{tabular}{|c|c|c|c|c|}
\hline $\begin{array}{c}\text { Kod } \\
\mathrm{e}\end{array}$ & Kriteria & Type & $\begin{array}{c}\text { Bobo } \\
t\end{array}$ & Satuan \\
\hline $\mathrm{K}_{1}$ & $\begin{array}{c}\text { Bahan } \\
\text { Pembuatan }\end{array}$ & $\begin{array}{c}\text { benefi } \\
t\end{array}$ & 2.2 & - \\
\hline $\mathrm{K}_{2}$ & $\begin{array}{c}\text { Pengatura } \\
\text { n Suhu }\end{array}$ & $\begin{array}{c}\text { benefi } \\
t\end{array}$ & 2.1 & ${ }^{\circ} \mathrm{C}$ \\
\hline $\mathrm{K}_{3}$ & Garansi & $\begin{array}{c}\text { benefi } \\
t\end{array}$ & 2.1 & $\begin{array}{c}\text { Tahun/Bula } \\
n\end{array}$ \\
\hline $\mathrm{K}_{4}$ & Harga & cost & 1.8 & Rp. \\
\hline $\mathrm{K}_{5}$ & Ukuran & cost & 1.8 & $P \times L \times T$ \\
\hline
\end{tabular}

\section{Memasukan Nilai Kriteria tiap Alternatif}

Berdasarkan data pada tabel 7 dan tabel 8 dapat dibuat tabel sebagai berikut :

Tabel 2.9 Nilai Kriteria tiap Alternatif

\begin{tabular}{|c|c|c|c|c|c|}
\hline \multirow[b]{2}{*}{ Alternatif } & \multicolumn{5}{|c|}{ Kriteria } \\
\hline & $\underline{K_{1}}$ & $\underline{K_{2}}$ & $K_{3}$ & $\underline{\mathrm{K}_{4}}$ & $\underline{K_{5}}$ \\
\hline$A_{1}$ & 40 & 50 & 50 & 40 & 30 \\
\hline$A_{2}$ & 50 & 50 & 30 & 40 & 30 \\
\hline $\mathrm{A}_{3}$ & 30 & 50 & 40 & 50 & 40 \\
\hline $\mathrm{A}_{4}$ & 40 & 50 & 30 & 40 & 50 \\
\hline$A_{5}$ & 20 & 20 & 30 & 50 & 40 \\
\hline$A_{6}$ & 40 & 50 & 50 & 30 & 40 \\
\hline$A_{1}$ & 40 & 50 & 50 & 40 & 30 \\
\hline
\end{tabular}

\section{Membuat Matriks Keputusan}

Berdasarkan nilai pada tabel 9 diperoleh data matrik keputusan $(\mathrm{X})$ sebgai berikut:

$$
X=\left[\begin{array}{lllll}
40 & 50 & 50 & 40 & 30 \\
50 & 50 & 30 & 40 & 30 \\
30 & 50 & 40 & 50 & 40 \\
40 & 50 & 30 & 40 & 50 \\
20 & 20 & 30 & 50 & 40 \\
40 & 50 & 50 & 30 & 40
\end{array}\right]
$$

\section{Membuat Matriks Normalisasi}

Langkah berikutnya, sesuai dengan persamaan [MOO-02] adalah menentukan nilai normalisasi untuk tiap kriteria dari setiap alternatif, dan membuatnya menjadi sebuah matriks Normalisasi. Perhitungan detailnya untuk tiap kriteria dan alternatif adalah sebagai berikut:

Normalisasi Kolom 1 (Kolom Kriteria 'Bahan Pembuatan'(K $\left.K_{1}\right)$ )
Normalisasi Matriks(1,1)- baris 1 kolom 1

$\mathrm{x}^{*}{ }_{1,1}=\mathrm{x}_{1,1} / \sqrt{ }\left(\mathrm{x}^{2}{ }_{1,1}+\mathrm{x}^{2}{ }_{2,1}+\mathrm{x}^{2}{ }_{3,1}+\mathrm{x}^{2}{ }_{4,1}+\mathrm{x}^{2}{ }_{5,1}+\mathrm{x}^{2}{ }_{6,1}\right)$

$x_{1,1}^{*}=40 / \sqrt{ }\left(40^{2}+50^{2}+30^{2}+40^{2}+20^{2}+40^{2}\right)$

$x_{1,1}^{*}=40 / \sqrt{8600}=40 / 92.736184954957$

$\mathrm{x}^{*}{ }_{1,1}=0.43133109281375$

Normalisasi Matriks(2,1)- baris 2 kolom 1

$\mathrm{x}_{2,1}^{*}=\mathrm{x}_{2,1} / \sqrt{ }\left(\mathrm{x}^{2}{ }_{1,1}+\mathrm{x}^{2}{ }_{2,1}+\mathrm{x}^{2}{ }_{3,1}+\mathrm{x}^{2}{ }_{4,1}+\mathrm{x}^{2}{ }_{5,1}+\mathrm{x}^{2}{ }_{6,1}\right)$

$\mathrm{x}_{2,1}^{*}=50 / \sqrt{ }\left(40^{2}+50^{2}+30^{2}+40^{2}+20^{2}+40^{2}\right)$

$x_{2,1}^{*}=50 / \sqrt{8600}=50 / 92.736184954957$

$\mathrm{x}_{2,1}^{*}=0.53916386601719$

Normalisasi Matriks $(3,1)$ - baris 3 kolom 1

$x_{3,1}^{*}=x_{3,1} / \sqrt{ }\left(x^{2}{ }_{1,1}+x^{2}{ }_{2,1}+x^{2}{ }_{3,1}+x^{2}{ }_{4,1}+x^{2}{ }_{5,1}+x^{2}{ }_{6,1}\right)$

$x^{*}{ }_{3,1}=30 / \sqrt{ }\left(4 O^{2}+5 O^{2}+3 O^{2}+4 O^{2}+20^{2}+40^{2}\right)$

$x_{3,1}^{*}=30 / \sqrt{ } 8600=30 / 92.736184954957$

$x_{3,1}^{*}=0.32349831961032$

Normalisasi Matriks(4,1)- baris 4 kolom 1

$\mathrm{x}_{4,1}^{*}=\mathrm{x}_{4,1} / \sqrt{ }\left(\mathrm{x}^{2}{ }_{1,1}+\mathrm{x}^{2}{ }_{2,1}+\mathrm{x}^{2}{ }_{3,1}+\mathrm{x}^{2}{ }_{4,1}+\mathrm{x}^{2}{ }_{5,1}+\mathrm{x}^{2}{ }_{6,1}\right)$

$\mathrm{x}^{*}{ }_{4,1}=40 / \sqrt{ }\left(40^{2}+50^{2}+30^{2}+40^{2}+20^{2}+40^{2}\right)$

$\mathrm{x}_{4,1}^{*}=40 / \sqrt{ } 8600=40 / 92.736184954957$

$\mathrm{x}_{4,1}^{*}=0.43133109281375$

Normalisasi Matriks $(5,1)$ - baris 5 kolom 1

$\mathrm{x}_{5,1}^{*}=\mathrm{x}_{5,1} / \sqrt{ }\left(\mathrm{x}^{2}{ }_{1,1}+\mathrm{x}^{2}{ }_{2,1}+\mathrm{x}^{2}{ }_{3,1}+\mathrm{x}^{2}{ }_{4,1}+\mathrm{x}^{2}{ }_{5,1}+\mathrm{x}_{6,1}{ }_{6,1}\right)$

$\mathrm{x}^{*}{ }_{5,1}=20 / \sqrt{ }\left(40^{2}+50^{2}+30^{2}+40^{2}+20^{2}+40^{2}\right)$

$\mathrm{x}^{*}{ }_{5,1}=2 \mathrm{O} / \sqrt{8600}=20 / 92.736184954957$

$\mathrm{x}^{*}{ }_{5,1}=0.21566554640688$

Normalisasi Matriks $(6,1)$ - baris 6 kolom 1

$\mathrm{x}_{6,1}^{*}=\mathrm{x}_{6,1} / \sqrt{ }\left(\mathrm{x}^{2}{ }_{1,1}+\mathrm{x}^{2}{ }_{2,1}+\mathrm{x}^{2}{ }_{3,1}+\mathrm{x}^{2}{ }_{4,1}+\mathrm{x}^{2}{ }_{5,1}+\mathrm{x}^{2}{ }_{6,1}\right)$

$x_{6,1}^{*}=40 / \sqrt{ }\left(4 O^{2}+50^{2}+30^{2}+40^{2}+20^{2}+40^{2}\right)$

$x_{6,1}^{*}=40 / \sqrt{8600}=40 / 92.736184954957$

$x_{6,1}^{*}=0.43133109281375$

Cara yang sama untuk menghitung normalisasi Kolom 2 (Kolom Kriteria 'Pengaturan Suhu'(K2)), Normalisasi Kolom 3 (Kolom Kriteria 'Garansi'(K3)), Normalisasi Kolom 4 (Kolom Kriteria 'Harga'(K4)) dan Normalisasi Kolom 5 (Kolom Kriteria 'Ukuran'(K5)). Dari perhitungan nilai normalisasi di atas, maka diperoleh matriks Nilai Normalisasi $\left(X^{*}\right)$ sebagai berikut:

$$
X^{*}=\left[\begin{array}{ccccc}
0.43 & 0.44 & 0.52 & 0.39 & 0.31 \\
0.54 & 0.44 & 0.31 & 0.39 & 0.31 \\
0.32 & 0.44 & 0.41 & 0.48 & 0.42 \\
0.43 & 0.44 & 0.31 & 0.39 & 0.52 \\
0.22 & 0.18 & 0.31 & 0.48 & 0.42 \\
0.43 & 0.44 & 0.52 & 0.29 & 0.42
\end{array}\right]
$$

\section{Menghitung Nilai Optimasi}

Perhitungan Nilai Optimasi Multiobjektif MOORA (maxmin) dalam contoh kasus ini mengacu pada persamaan [MOO-04] karena tiap kriteria memiliki bobot (W) tersendiri. Nilai optimasi ini dihitung untuk setiap alternatif yang diberikan. Nilai tersebut merupakan jumlah perkalian bobot kriteria dengan nilai atribut 
maksimun ( $\max$ ) yaitu nilai atribut bertipe benefit dikurangi dengan jumlah perkalian dari bobot kriteria dengan nilai atribut minimum ( $\mathrm{min}$ ) yaitu nilai atribut bertipe cost. Perhitungan manualnya ditunjukkan seperti dalam perhitungan berikut ini:

\section{Perhitungan Nilai Optimasi untuk Alternatif $1\left(y^{*} 1\right)$}

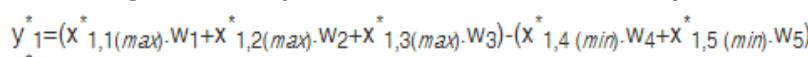
$y^{*}{ }_{1}=((0.43 * 2.2)+(0.44 * 2.1)+(0.52 * 2.1))-((0.39 * 1.8)+(0.31 * 1.8))$

$\mathrm{y}^{*}{ }_{1}=2.9622011352991-1.2621240839427$

$y_{1}^{*}=1.7000770513564$

\section{Perhitungan Nilai Optimasi untuk Alternatif $2(y * 2)$}

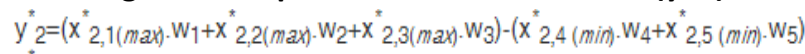
$y_{2}^{*}=((0.54 * 2.2)+(0.44 * 2.1)+(0.31 * 2.1))-((0.39 * 1.8)+(0.31 * 1.8))$

$\mathrm{y}_{2}^{*}=2.7639135245599-1.2621240839427$

$y_{2}^{*}=1.5017894406172$

Cara yang sama untuk menghitung nilai optimasi untuk Alternatif $3\left(y^{*} 3\right)$ dengan nilai akhir 0.88238125577728, Alternatif $4\left(y^{*} 4\right)$ mendapatkan nilai akhir 0.88717479834973 , Alternatif $5(y * 5) 0.12729477214882$ dan Alternatif $6 \quad\left(y^{*} 6\right)$ dengan nilai akhir 1.6853983487747.

\section{Menentukan Ranking}

Dari hasil perhitungan Nilai Optimasi sebelumnya, dapat diurutkan hasilnya dari yang terbesar sampai yang terkecil; dimana nilai optimasi dari alternatif yang terbesar merupakan alternatif terbaik dari data yang ada dan merupakan alternatif yang terpilih, sedangkan alternatif dengan nilai optimasi terendah adalah yang terburuk dari data yang ada. Dalam urutan dari yang terbesar sampai dengan yang terkecil, diperoleh :

$\mathrm{y}^{*} 1=1.7000770513564$

$y^{*} 6=1.6853983487747$

$y * 2=1.5017894406172$

$\mathrm{y}^{*} 4=0.88717479834973$

$y^{*} 3=0.88238125577728$

$\mathrm{y}^{*} 5=-0.12729477214882$

Sehingga hasil akhir dari Sistem Pendukung Keputusan menggunakan Metode MOORA ini adalah dipilih alternatif $\mathrm{y}^{* 6}$ (Philips Curly HP 8605) dengan Nilai Optimasi sebesar 1.6853983487747

\section{Perancangan Sistem}

DFD Konteks seleksi siswa baru kelas unggulan

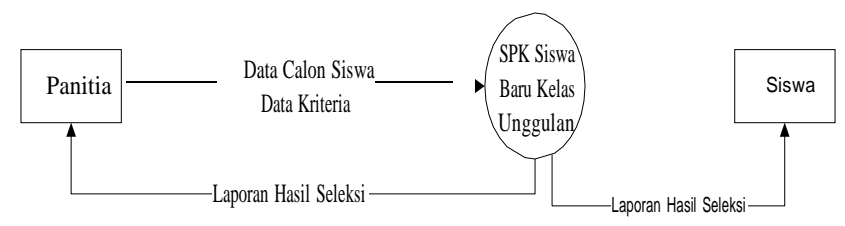

Gambar 2.1 Data Flow Diagram (Konteks)

DFD level 1 Seleksi Siswa Baru

Desain Sistem menggunakan data flow diagram seperti yang gambar berikut ini :
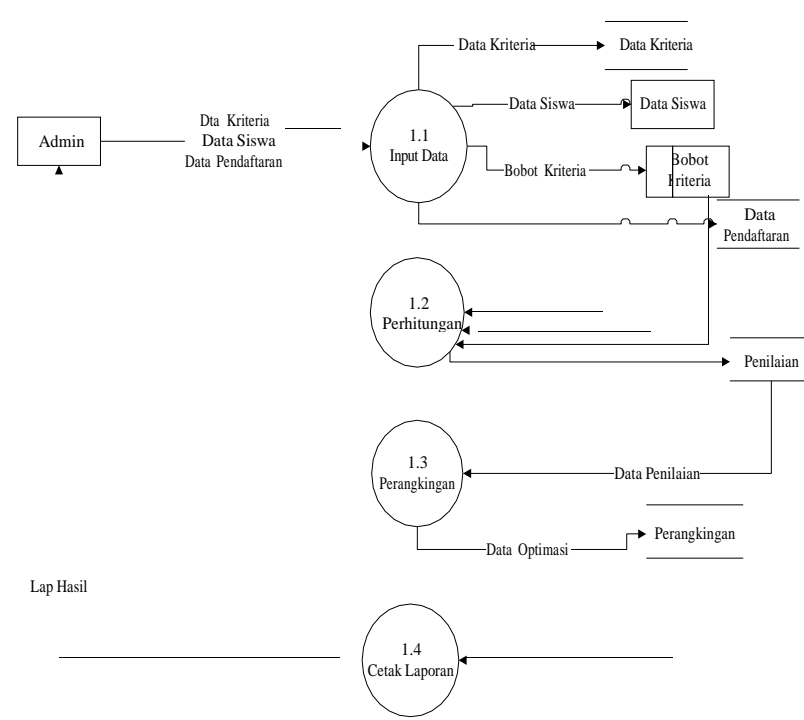

Gambar 2.2 Data Flow Diagram (Level 1)

Proses dalam sistem dimulai dengan melakukan input data siswa, data kriteria dan data pendaftaran. Kemudian dilanjutkan dengan proses perhitungan yang akan menghasilakan penilaian siswa baru kelas unggulan.

3. Hasil

Dalam menentukan siswa kelas unggulan, penilaian yang digunakan yaitu dengan metode MOORA, dimana kriteria dan bobot kriteria yang di dapat berpedoman pada hasil wawancara dengan kepala MTs N 1 Lombok Tengah, yang mana Kepala Sekolah sebagai pimpinan teratas dalam sekolah memiliki kewenangan penuh untuk menentukan kriteria. Adapun bobot kriteria yang dinilai yaitu nilai raport, mempunyai piagam, nilai ujian nasional, nilai ujian seleksi dan nilai mengaji.

Tabel 3.1 Indikator Kriteria Penilaian

\begin{tabular}{cc}
\hline No & Kriteria \\
\hline 1 & Nilai raport \\
2 & Piagam \\
3 & Nilai Ujian nasional
\end{tabular}

Program Studi Teknik Informatika 

4
5
Nilai ujian seleksi
Nilai mengaji

\section{Pembobotan Kriteria}

Berikut ini adalah pembobotan nilai dari kriteria yang telah ditentukan

Tabel 3.2 Pembobotan Kriteria yang telah ditentukan

\begin{tabular}{lll}
\hline No & Kriteria & Bobot Kriteria \\
\hline 1 & Nilai raport & $20 \%$ \\
2 & Piagam & $10 \%$ \\
3 & Nilai ujian nasional & $20 \%$ \\
4 & Nilai ujian seleksi & $30 \%$ \\
5 & Nilai mengaji & $20 \%$
\end{tabular}

\section{Skala Penilaian}

\begin{tabular}{llll}
\multicolumn{4}{c}{ Tabel 3.3 Skala Penilaian } \\
\hline No & Kriteria & Angka & Keterangan \\
\hline 1 & Nilai raport & $80-100$ & Sangat baik \\
& & $60-79$ & Baik \\
& & $40-59$ & Cukup baik \\
& & $0-39$ & Kurang \\
2 & Piagam & 1 & Ya \\
& & 0 & Tidak \\
3 & Nilai Ujian & $80-100$ & Sangat baik \\
& nasional & $60-79$ & Baik \\
& & $40-59$ & Cukup baik \\
& & $0-39$ & kurang \\
4 & Nilai ujian & $80-100$ & Sangat baik \\
& seleksi & & \\
& & $60-79$ & Baik \\
& & $40-59$ & Cukup baik \\
& & $0-39$ & Kurang \\
5 & Nilai & $80-100$ & Sangat baik \\
& mengaji & $60-79$ & Baik \\
& & $40-59$ & Cukup baik \\
& & $0-39$ & Kurang
\end{tabular}

\section{Menu Login}

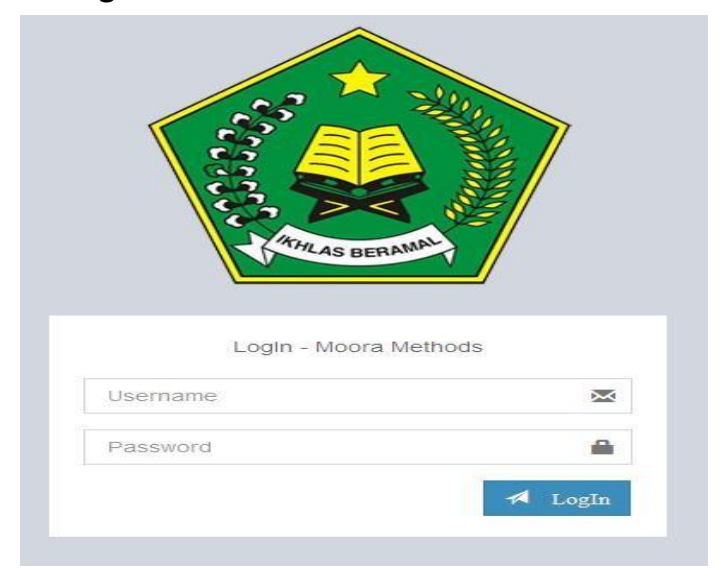

Program Studi Teknik Informatika

Universitas Prima Indonesia (UNPRI) Medan

\section{Gambar 3.1 InterfaceLogin}

Admin dapat masuk ke halaman utama dengan memasukkan username dan password dengan benar

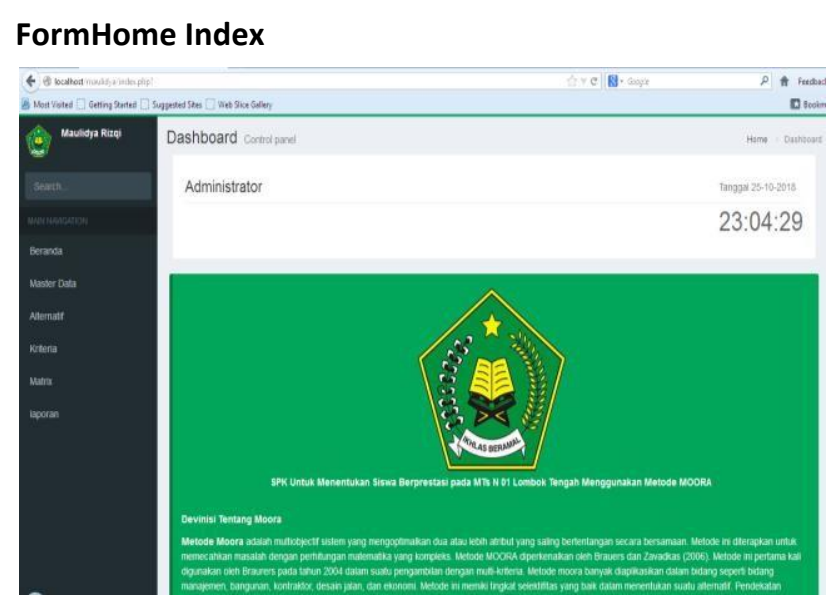

Gambar 3.2 Interface halaman Home Index

Halaman index merupakan halaman menu utama website sistem pendukung keputusan

\section{InterfaceFormInput Data Calon Siswa}

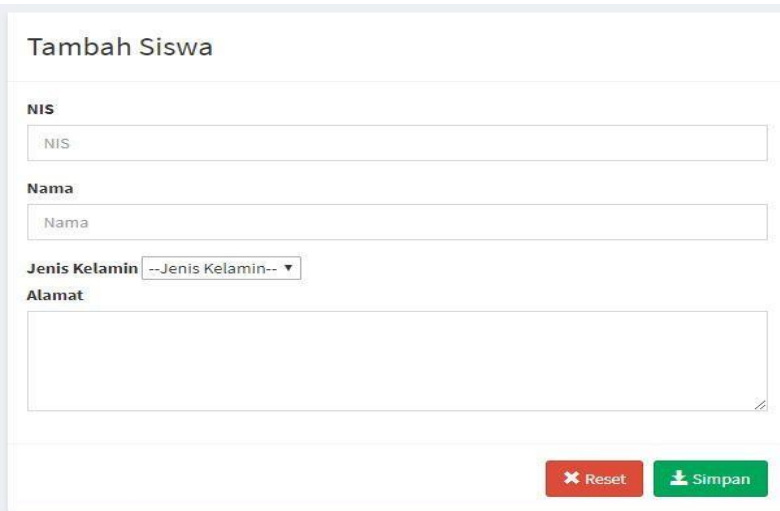

Gambar 3.3 Interface halaman formInputData Calon SIswa

Pada form data calon siswa diinputkan oleh admin, dapat dilihat pada gaambar 4.3 Forminput data calon siswa

Form Data Calon Siswa 


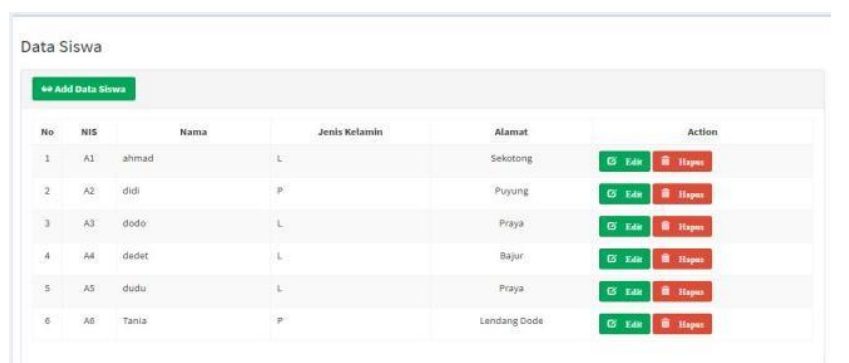

Gambar 3.4 InterfaceFormData Calon Siswa

Form data calon siswa ini berisi data yang sudah diinputkan oleh admin

\section{Form Normalisasi Matriks}

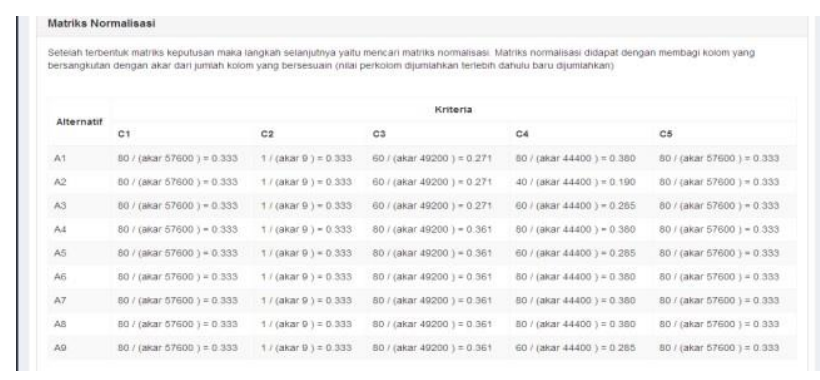

Gambar 3.5Form Normalisasi Matriks

Setelah terbentuk matriks keputusan maka langkah selanjutnya yaitu mencari matriks normalisasi. Matriks normalisasi didapat dengan membagi kolom yang bersangkutan dengan akar dari jumlah kolom yang bersesuain (nilai perkolom dijumlahkan terlebih dahulu baru dijumlahkan)

\section{Form Normalisasi Matriks Terbobot}

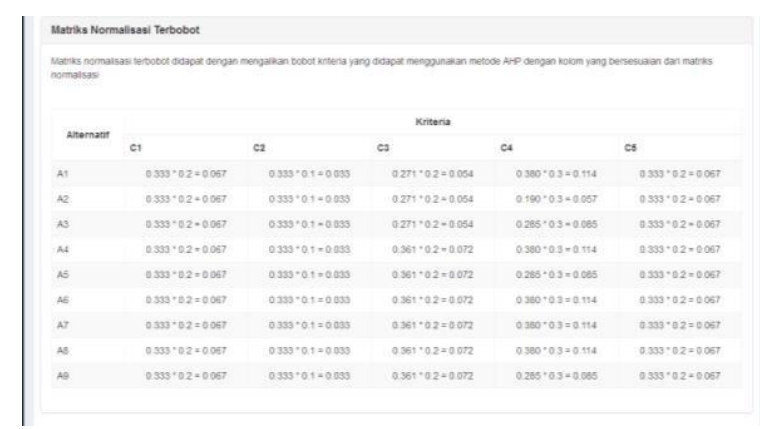

Gambar 3.6 Form Matriks Normalisasi Terbobot

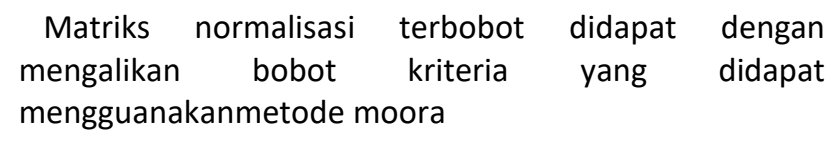

FormPerangkingan

Program Studi Teknik Informatika

Universitas Prima Indonesia (UNPRI) Medan

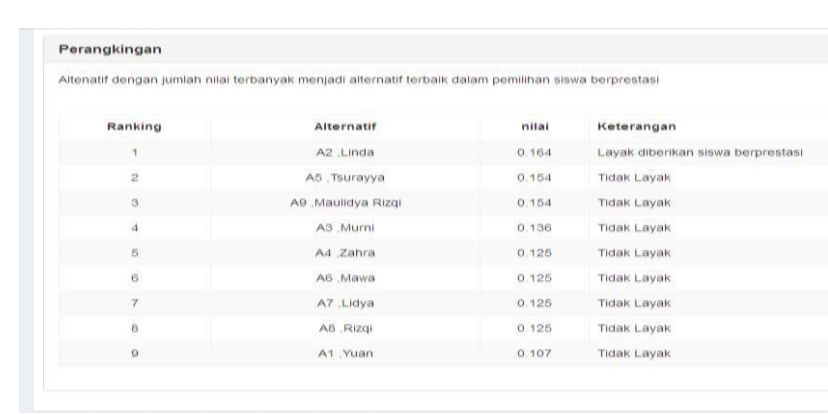

Gambar 3.7 FormPerangkingan

Alternatif dengan jumlah nilai terbanyak menjadi alternatif terbaik dalam memilih siswa terbaik.

\section{Kesimpulan}

Berdasarkan penelitian yang dilakukan oleh penulis pada sistem pendukung keputusan pemilihan siswa baru kelas unggulan menggunakan metode MOORA dapat diambil kesimpulan yaitu Aplikasi sistem pendukung keputusan ini dapat mempermudah proses pemilihan siswa baru kelas unggulan Pada bagian ini harus menyatakan dengan jelas kesimpulan utama dan memberikan penjelasan tentang pentingnya dan relevansi studi ke lapangan, kelebihan dan kekurangan, serta kemungkinan pengembangan penelitian lanjutan.

\section{Referensi}

[1] Abdul Kadir, 2003, Pengenalan Sistem Informasi, Andi, Yogyakarta.16 april 2018

[2] Andri Kristanto, 2008, perancangan system informasi dan aplikasinya, Gava. 16 april 2018

[3] Brauers, W. K. 2002. The multiplicative representation for multiple objective optimization with an application for arms procurement, Naval Research Logistics 49: 327-340.

[4] Brauers, W. K.; Zavadskas, E. K.; Turskis, Z.; Vilutiene, $\mathrm{T} ;$ 2008. Multi-objective contractor's ranking by applying the Moora method, Journal of Business Economics and Management 9: 245255.

[5] Dinas PSDA NT-1. 2015. Pelatihan operasi jaringan irigasi dan pengisian blangko operasi. 16 april 2018

[6] Fadli, Sofiansyah. "Sistem Pendukung Keputusan Evaluasi Kinerja Guru Honorer SMA Menggunakan Metode Penyelesaian MADM", Semnasinotek, Vol.2, No.1, Hal: 321-327, Maret 2018.

[7] Fadli, Sofiansyah. "Sistem Pendukung Keputusan Evaluasi Kinerja Kepala Sekolah SMA/SMK Kabupaten Lombok Tengah NTB", Semnasinotek, Vol.1, No.1, Hal: 299-308, Februari 2017. 
[8] Gadakh. V. S. 2011. Application of MOORA method for parametric optimization of milling process. Vol 1, no 4, 2011. India

[9] Indarto, "desain fitur dan implementasi system informasi daerah irigasi (studikasus : daerah irigasi sampean baru)", Kampus Tegal boto, Jember.2015.

[10] Ozcelik, G., Aydogan, E.K., Gencer, c. 2014. A hybrid MOORA-Fuzzy algorithm for special education and rehabilitation center selection, journal of military and information science, 2(3), 53-63. German.

[11] Patirajawane, Fauriza, "studi optimasi distribusi pemanfaatan air di Daerah Irigasi Melik Kabupaten Jombangdengan menggunakan program linear", Universitas Brawijaya.2013.

[12] Sa'adati,Yuan., Fadli, Sofiansyah., Khairul, Imtihan. "Analisis Penggunaan Metode AHP dan MOORA untuk Menentukan Guru Berprestasi sebagai Ajang Promosi Jabatan", SINKRON, Vol.3, No.1, Hal: 8290, Oktober 2018.
[13] Susanto, Azhar. "Sistem Informasi Manajemen Konsep dan Pengembangannya". Lingga Jaya. Bandung. 2004.

[14] Undang-undang No. 20 Tahun 2003 tentang Sistem Pendidikan Nasional 